\title{
Bioremediation of a Drilling Waste-Contaminated Soil; Biotreatability Assessment and Microcosm Optimization for Developing a Field-Scale Remediation Process
}

\author{
Masumeh Shaeyan, Hassan Tirandaz, Somayeh Ghanbarpour, Nasim Seyedipour, Mahmoud Shavandi, \\ Seyed Mohammad Mehdi Dastgheib*
}

Microbiology and Biotechnology Research Group, Research Institute of Petroleum Industry, Tehran, Iran

"Corresponding author: Seyed Mohammad Mehdi Dastgheib, Microbiology and biotechnology research group, Research institute of petroleum industry, Tehran, Iran. Tel: +98-21-48255143, Fax: +98-21-44739736, E-mail: Dastgheibsmm@ripi.ir

Received: 6 Jun. 2015；～Revised: 22 May. 2018；Ａccepted: 23 May. 2018; $\quad$ Published online: 11 Aug. 2018

\begin{abstract}
Background: Petroleum drilling and exploration operations generate a significant amount of oily wastes. Comparing with physical and chemical remediation methods, bioremediation is cost-effective, highly efficient, and environment-friendly technology.

Objectives: The aim of this study was to evaluate biological treatment efficiency for an oil-contaminated soil prepared from an abandoned drilling mud pit located in the Khangiran region, Khorasan Razavi Provinvce, Iran.

Materials and Methods: Following chemical analysis of the contamination, isolation and phylogenetic analysis of the predominant hydrocarbon-utilizing bacteria were performed in order to elucidate microbial diversity. Afterwards, the full factorial design was used to optimize the concentration of nitrogen $(0,100,250$, and $500 \mathrm{ppm})$ and phosphate $(0,10,25$, and $50 \mathrm{ppm}$ ) in the soil. The prepared microcosms were incubated at $30^{\circ} \mathrm{C}$ for a 60 -day period. The total heterotrophic bacterial content was enumerated during bioremediation process. The total petroleum hydrocarbon concentration was analyzed after 60 days to evaluate biodegradation extent.

Results: The mud pit was mainly contaminated with the weathered diesel compounds ranging from $\mathrm{C}_{12}$ to $\mathrm{C}_{30}$. Investigation of the indigenous microflora showed that a variety of hydrocarbon-utilizing bacteria were present in the untreated soil dominated by Actinobacteria including the genera Gordonia, Nocardia, Nocardioides, and Rhodococcus. The full-factorial soil microcosms' nutrient optimization indicated that nitrogen amendment could be the most effective at $250 \mathrm{ppm}$, while excess nitrogen would lead to a diminished microbial activity. The main effect statistical analysis demonstrated that addition of phosphate did not cause a significant improvement in the remediation process. In the optimal nutrient conditions, the total microbial count increased from $1.76 \times 10^{7} \mathrm{CFU} . \mathrm{g}^{-1}$ to $1.24 \times 10^{9} \mathrm{CFU} \cdot \mathrm{g}^{-1}$ and led into $75.4 \% \mathrm{w} / \mathrm{w}$ biodegradation in two months, while in the control microcosm without nutrient amendment only $36.6 \%$ of the depletion was observed.

Conclusions: These results indicate that biostimulation could be a promising candidate for a successful field-scale bioremediation process in the studied drilling mud pit.

Keywords: Bioremediation, Diesel, Mud pit, Microflora, Nutrient optimization, Oil-based drilling.
\end{abstract}

\section{Background}

The spillage of the oil and related products has triggered soil contamination and critical environmental impacts in the last decades. Among a variety of the remediation methods application of the microbial processes for decontamination of the oil-polluted environments is a promising approach which has been focused recently (13). Bioremediation has been recognized as an efficient, economic, versatile, environmental friendly solution, and could be performed by either bioaugmentation (adding microorganisms) or biostimulation (introducing nutrients) (4-6). While the success of the addition of the pollutant-degrading bacteria is ambiguous, and should be investigated cautiously prior to each implementation (7), biostimulation has been recognized as an efficient and economic cleanup method both in aquatic and

Copyright (C) 2017 The Author(s); Published by National Institute of Genetic Engineering and Biotechnology. This is an open access article, distributed under the terms of the Creative Commons Attribution-NonCommercial 4.0 International License (http://creativecommons.org/licenses/ by-nc/4.0/) which permits others to copy and redistribute material just in noncommercial usages, provided the original work is properly cited. 
terrestrial environments (8). The natural population of the microorganisms play an important role in the removal of petroleum related pollutants. Hydrocarbon degradation ability is not limited to a few genera of the microorganisms (9). Prince et al. (2010) have listed more than 175 genera of the prokaryotic hydrocarbon degraders (bacteria and archaea) from various phyla (including Actinobacteria, Bacteroidetes, DeinococcusThermus, and Proteobacteria) (8). It is generally assumed that in a chronically contaminated soil, the diverse hydrocarbon degraders are selected and enriched among indigenous microbial community (10). Considering the enormous variety of compounds in the complex mixtures such as crude oil or refinery fractions, the individual microorganisms are not expected to possess the metabolic potential for a complete degradation of the pollution, and hence a diverse microbial assemblage is required in order to oil spill cleanup (11). The success of the biostimulation is entirely dependent on the potential of the indigenous microorganisms and it is necessary to perform a comprehensive microbial analysis of the oil contaminated environment (12). Furthermore, evaluating the limiting physical and chemical factors for the biodegradation activity of the native microorganisms is critical prior to the field application of the bio stimulation (12).

Various factors such as quality and quantity of the hydrocarbons, $\mathrm{pH}$, temperature, the presence of electron acceptors, and nutrient concentrations may influence the biodegradation rate and must be well tuned during bioremediation process $(13,14)$. Among the critical factors, an unbalanced C: N: P ratio caused by the high carbon levels in the oil spills is a wellknown impediment in biodegradation. Consequently, optimization of the remediation process generally involves the addition of appropriate quantities of the nitrogen and phosphorous containing fertilizers $(7,15$ 17). The optimal ratio of nutrients has been copiously discussed in the literature, but in overall, each system represents its own optimal nutrient ratio depending on the carbon concentration and the type, the presence, and bioavailability of the soil nutrients, as well as intrinsic soil microbial potential which must be studied and adjusted prior to the field operation (18). Alexander et al. (19) have reported that a C: N: P ratio of 100:10:2 was optimal in their experimental conditions, while Zhang et al. (20) have found that the ratio of 100:5:1 was the best nutrient combination and Vieira et al. (18) have reported the ratio of 100:20:2.75, respectively.

\section{Objectives}

In the present study, the physico-chemical and the microbial properties of the oil-contaminated soil of an abandoned drilling mud pit was investigated. The efficiency of the biological treatment was evaluated and optimized according to the nutrient requirements.

\section{Materials and Methods}

\subsection{Soil Description}

The studied soil was obtained from an abandoned drilling mud pit in the Khangiran region, Northeast of Iran (N $36^{\circ} 33^{\prime} \mathrm{E} 60^{\circ} 47^{\prime}$ ), at an altitude of 365 meters above the sea level. The soil samples were sieved and well mixed to form a representative composite sample. Briefly, the soil was slightly saline (saturation extract EC of $7.22 \mathrm{dS} . \mathrm{m}^{-1}$ ) with a neutral $\mathrm{pH}(\mathrm{pH}$ 7.6). The soil texture was classified as sandy ( $78 \%$ sand, $10 \%$ silt, and $12 \%$ clay) with a low water holding capacity of $38.4 \%$. The total organic carbon, total nitrogen, and labile phosphorous were determined to be $3.25 \%(\mathrm{w} / \mathrm{w}), 0.05$ $\%(\mathrm{w} / \mathrm{w})$, and $3.42 \mathrm{ppm}$, respectively.

\subsection{Contamination Analysis}

Total petroleum hydrocarbon (TPH): the soil was extracted by $n$-hexane in a Soxhlet apparatus as described by standard method 5520F (21). Following to polar compounds clean-up through the florisil filter, the total petroleum hydrocarbon (TPH) was measured by gravimetric method (21). To determine carbon distribution of the extracted hydrocarbons, simulateddistillation GC was used. Based on ASTM D2887, a portion of the extracted hydrocarbons was injected into a CPC sil8/CB capillary column (length, $25 \mathrm{~m}$ ) in an Agilent gas chromatograph equipped with FID detector. GC temperature program started at $-70{ }^{\circ} \mathrm{C}$ and reached to $425{ }^{\circ} \mathrm{C}$ by a ramp rate of $15{ }^{\circ} \mathrm{C} \mathrm{min}^{-1}$ and kept constant for 1 minute.

Polycyclic aromatic compounds (PAHs) of US EPA priority list were analyzed according to the method developed by Samimi et al. (2009) using Waters highperformance liquid chromatography (HPLC) system equipped with the $\mathrm{C} 18$ column $(250 \times 4.6 \mathrm{~mm}$, particle size $5 \mu \mathrm{m})$ and a fluorescence detector (22).

\subsection{Microbial Analysis}

\subsubsection{Enumeration of the Microbial Population}

The total heterotrophic bacteria of the soil sample were estimated by the plate count method. Serial dilution of microbes was prepared and spread on $\mathrm{R}_{2} \mathrm{~A}$ agar medium amended with $0.5 \% \mathrm{w} / \mathrm{w} \mathrm{NaCl}$. Following to one week of incubation at $30{ }^{\circ} \mathrm{C}$, the colony-forming units (CFU) were counted in the plates with an appropriate number of colonies. 
The hydrocarbon-utilizing bacteria were enumerated by the three-tube the most-probable number (MPN) method (23), exploiting Bushnell-Haas broth amended with $0.5 \%(\mathrm{w} / \mathrm{v}) \mathrm{NaCl}$ and $2 \mathrm{~mL} . \mathrm{L}^{-1}$ gasoil. The tubes were incubated at $30{ }^{\circ} \mathrm{C}$ for one month, and bacterial growth was determined by culture turbidity method.

\subsubsection{Isolation of Hydrocarbon-Utilizing Bacteria}

For isolating the predominant hydrocarbon-utilizing bacteria the highest positive dilutions of the MPN tubes, were streaked on R2A agar plates amended with $0.5 \%$ $(\mathrm{w} / \mathrm{v}) \mathrm{NaCl}$. After two weeks of incubation at $30{ }^{\circ} \mathrm{C}$, distinct colonies were purified and tested to verify their hydrocarbon utilization ability in the minimal media containing $2 \mathrm{~mL} . \mathrm{L}^{-1}$ gasoil as the sole carbon source.

\subsection{Phylogenetic Analysis}

The genomic DNA of the dominant hydrocarbon-utilizing bacteria was extracted according to Wilson (2001) (24). The 16S rRNA genes were amplified and sequenced using 9F (5'-AAGAGTTTGATCATGGCTCAG-3') and 1541R (5'-AGGAGGTGATCCAACCGCA-3') universal primers. The obtained sequences were deposited in the GenBank under accession numbers of KF731646 through KF731653. The phylogenetic analysis was performed using the EzTaxon-e server (http://eztaxon-e. ezbiocloud.net/; Kim et al. 2012) (25) and Neighborjoining algorithm of the MEGA6 software was used to construct the phylogenetic tree. In each case, bootstrap values were calculated from 1000 replications (26).

\subsection{Nutrient Optimization}

Preparation of microcosms and experimental design: Based on previous experience and due to operational necessity in the field performance, an amount of $2 \%$ (w/w) of the compost was added to the soil to improve soil texture in microcosms. The utilized mature compost contained $48.1 \%$ of the organic carbon, a total amount of $1.59 \%$ nitrogen, $1 \%$ phosphorous (expressed as $\mathrm{P}_{2} \mathrm{O}_{5}$ ), and a high load of heterotrophic and hydrocarbonutilizing bacteria $\left(1.31 \times 10^{9} \mathrm{CFU} \cdot \mathrm{mL}^{-1}\right.$ and $1.1 \times 10^{8}$ MPN.mL ${ }^{-1}$, respectively).

The soil microcosms were prepared by placing 20 grams of the homogenized soil into sterile plates. To assess the requirement of the soil for further nutrients, the commercial fertilizers, namely urea (46\% Nitrogen) and super triple phosphate $\left(46 \% \mathrm{P}_{2} \mathrm{O}_{5}\right)$ were used as nitrogen and phosphorous sources. Considering the soil initial contamination level as a carbon source, four levels of nitrogen $(0,100,250$, and $500 \mathrm{ppm})$ and phosphorus $(0,10,25$, and $50 \mathrm{ppm})$ were prepared and investigated using the full factorial approach in triplicates. A control microcosm was also set up, containing contaminated soil with no other amendment, and was used as the baseline biodegradation activity of the soil.

The prepared microcosms were incubated at $30{ }^{\circ} \mathrm{C}$ for a 60 -day period. In order to maintain the soil water content at around $15 \% \mathrm{w} / \mathrm{w}$ during the experimental process, the weight of the soil in plates was periodically measured and water loss was compensated using sterile deionized water and mixed thoroughly. The number of the total heterotrophic bacteria of the soil samples was measured every 10 days by plate count method. The extent of biodegradation was evaluated by measuring $\mathrm{TPH}$ at the end of the experiment.

\section{Results}

\subsection{Soil Analysis}

The contaminated soil contained $26.58 \mathrm{mg} \cdot \mathrm{g}^{-1}$ of the total petroleum hydrocarbon. Based on simulated distillation, the initial and final boiling point of the extracted material were $208^{\circ} \mathrm{C}$ and $566^{\circ} \mathrm{C}$, respectively. The carbon distribution analysis showed that the remained hydrocarbons in the soil ranged from $\mathrm{C}_{12}$ to $\mathrm{C}_{30}$ with $\mathrm{C}_{22}$ as the most abundant compound. Among the polycyclic aromatic compounds, phenanthrene, naphthalene, and alkyl-naphthalenes were the most abundant with the concentrations of $31,5.6$, and 9.2 $\mathrm{mg} \cdot \mathrm{kg}^{-1}$, respectively.

\subsection{Soil Microbial Population}

The primary investigation o the homogenized soil sample showed that the soil sample comprises a potent indigenous microbial flora and could be a promising candidate for the biological treatment. The initial population of the soil hydrocarbon-utilizing and heterotrophic bacteria were $4.3 \times 10^{4}$ and 1.61 $\times 10^{7}$, respectively. By streaking the highest positive dilutions of the MPN tubes on R2A plates, 25 isolates were obtained among which only 8 strains could utilize hydrocarbon as the sole source of carbon and energy. Table 1 represents only dominant culturable hydrocarbon-utilizing bacteria isolated from the studied soil samples. Actinobacteria, including the genera Gordonia, Nocardia, Nocardioides, and Rhodococcus were the dominant hydrocarbonutilizing bacteria. Proteobacteria including the genera Rhizobium Rhizobium (Alphaproteobacteria) and Pseudomonas (Gammaproteobacteria) were also present in the soil sample (Table 1). The phylogenetic tree of the isolates and closely related bacteria is shown in Figure 1. 
Table 1. The closest relatives of the dominant culturable hydrocarbon utilizing bacteria isolated from the studied soil sample.

\begin{tabular}{|c|c|c|c|c|c|}
\hline Strain & $\begin{array}{l}\text { GenBank } \\
\text { accession } \\
\text { number }\end{array}$ & Most Related Strain & $\begin{array}{l}\text { GenBank } \\
\text { Accession } \\
\text { number }\end{array}$ & $\begin{array}{l}\text { Similarity } \\
(\%)\end{array}$ & $\begin{array}{l}\text { Taxonomical position } \\
\text { of isolate }\end{array}$ \\
\hline Khangiran2 & KF731646 & Rhizobium halotolerans $\mathrm{AB} 21$ & JX307098 & 100 & $\begin{array}{l}\text { Proteobacteria, } \\
\text { Alphaproteobacteria, } \\
\text { Rhizobiales, } \\
\text { Rhizobiaceae }\end{array}$ \\
\hline Khangiran3 & KF731647 & Gordonia westfalica $\mathrm{Kb} 2$ & AJ312907 & 99.64 & $\begin{array}{l}\text { Actinobacteria, } \\
\text { Actinobacteria, } \\
\text { Corynebacteriales, } \\
\text { Nocardiaceae }\end{array}$ \\
\hline Khangiran7 & KF731648 & $\begin{array}{l}\text { Rhodococcus rhodochrous } \\
\text { DSM } 43241\end{array}$ & X79288 & 99.34 & $\begin{array}{l}\text { Actinobacteria, } \\
\text { Actinobacteria, } \\
\text { Corynebacteriales, } \\
\text { Nocardiaceae }\end{array}$ \\
\hline Khangiran 10 & KF731649 & R. rhodochrous DSM 43241 & X79288 & 99.71 & $\begin{array}{l}\text { Actinobacteria, } \\
\text { Actinobacteria, } \\
\text { Corynebacteriales, } \\
\text { Nocardiaceae }\end{array}$ \\
\hline Khangiran16 & KF731650 & $\begin{array}{l}\text { Nocardia asteroides NBRC } \\
15531\end{array}$ & BAFO01000006 & 99.85 & $\begin{array}{l}\text { Actinobacteria, } \\
\text { Actinobacteria, } \\
\text { Corynebacteriales, } \\
\text { Nocardiaceae }\end{array}$ \\
\hline Khangiran20 & KF731651 & $\begin{array}{l}\text { Pseudomonas balearica } \\
\text { SP1402 }\end{array}$ & U26418 & 99.79 & $\begin{array}{l}\text { Proteobacteria, } \\
\text { Gammaproteobacteria, } \\
\text { Pseudomonadales, } \\
\text { Pseudomonadaceae }\end{array}$ \\
\hline Khangiran22 & KF731652 & G. alkanivorans NBRC 16433 & BACI01000096 & 99.93 & $\begin{array}{l}\text { Actinobacteria, } \\
\text { Actinobacteria, } \\
\text { Corynebacteriales, } \\
\text { Nocardiaceae }\end{array}$ \\
\hline Khangiran25 & KF731653 & $\begin{array}{l}\text { Nocardioides aromaticivorans } \\
\text { H-1 }\end{array}$ & AB087721 & 97.71 & $\begin{array}{l}\text { Actinobacteria, } \\
\text { Actinobacteria, } \\
\text { Propionibacteriales, } \\
\text { Nocardioidaceae }\end{array}$ \\
\hline
\end{tabular}

\subsection{Nutrients Optimization}

The basal biodegradation extent after 60 days of the incubation was measured as $36.6 \% \mathrm{w} / \mathrm{w}$ in the contaminated soil control microcosm. Compost amendment has slightly increased biodegradation up to $40.0 \% \mathrm{w} / \mathrm{w}$ due to both nutritional factors of compost and hydrocarbon degradation effect of its microbial flora. According to the data presented in Figure 2, the highest TPH removal efficiency of $75.4 \% \mathrm{w} / \mathrm{w}$ was observed in microcosm with $250 \mathrm{ppm}$ nitrogen with no phosphate amendment. Statistical analysis of the main effects of the parameters (using Minitab software) confirmed that nitrogen was by far the most effective factor in biodegradation process in comparison to phosphate (Fig. 3). Remarkably, the excess amount of nitrogen source could have a negative effect on the biodegradation, as well.

\subsection{Microbial Changes}

The result obtained by counting the total heterotrophic bacteria showed that the microbial population of all soil samples was increased during the first 10 days of the experiment. The microbial growth rates were greater for the soil samples amended with a higher amount of nitrogen (Fig. 4). Although an outstanding growth peak was observed after 20 days of incubation in 250 


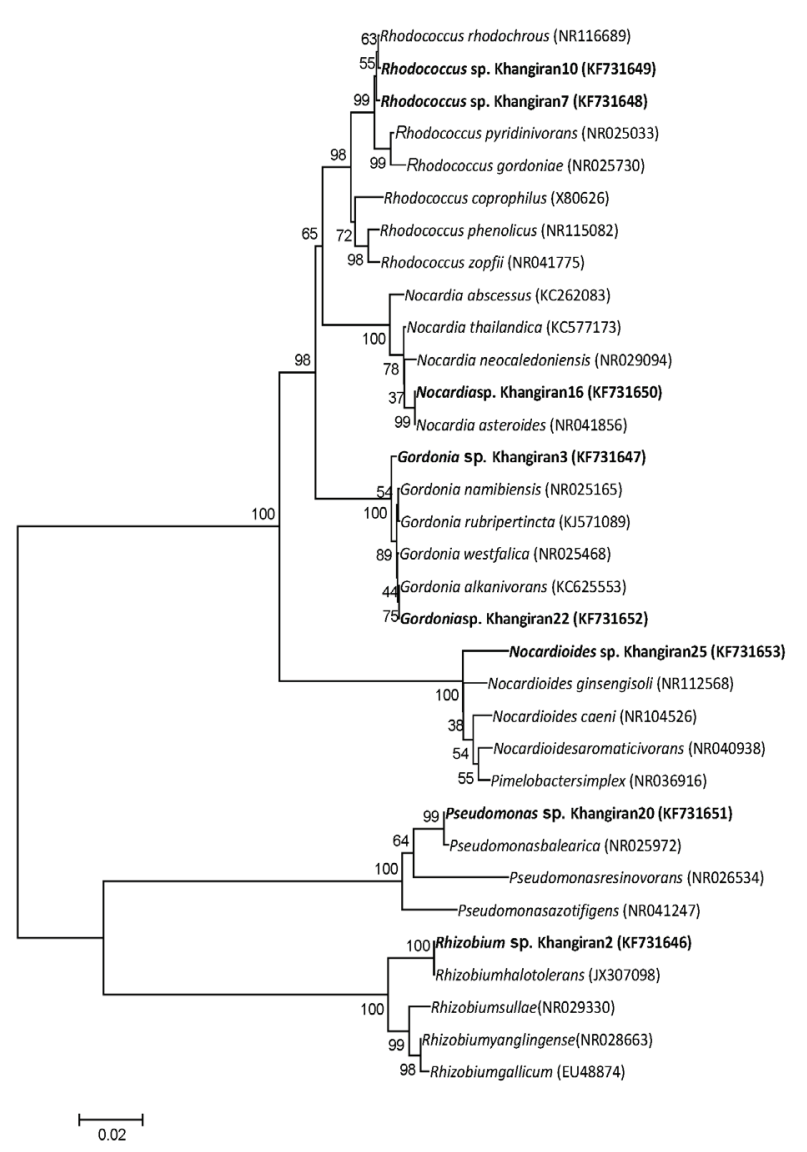

Figure 1. The Neighbor-joining phylogenetic tree based on 16S rRNA gene sequences showing the position of the hydrocarbon utilizing bacteria and closely related species of the related genera. The GenBank accession numbers are presented in the parentheses. Bootstrap values (\%) are based on 1000 replicates and presented bar indicates a value of 0.02 substitutions per nucleotide position.

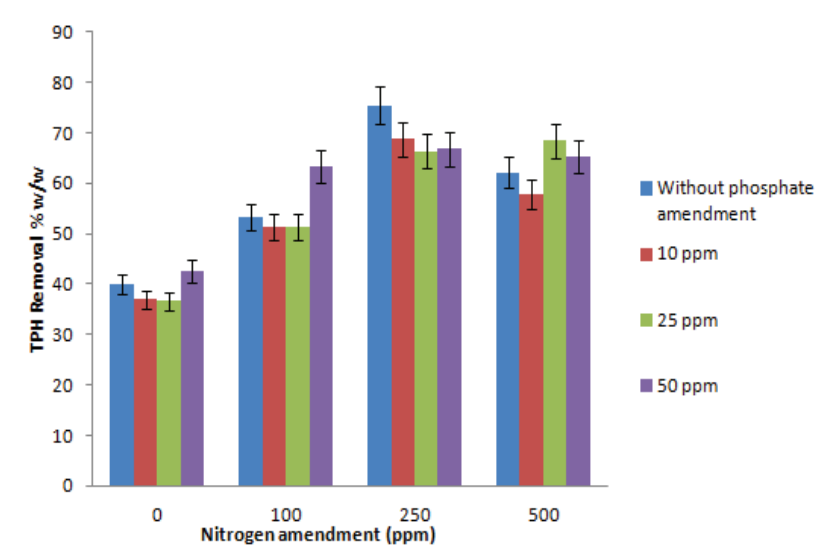

Figure 2. The extent of biodegradation obtained in the designed experimental microcosms after 60 days. Error bars represent standard deviations of the three replicates.

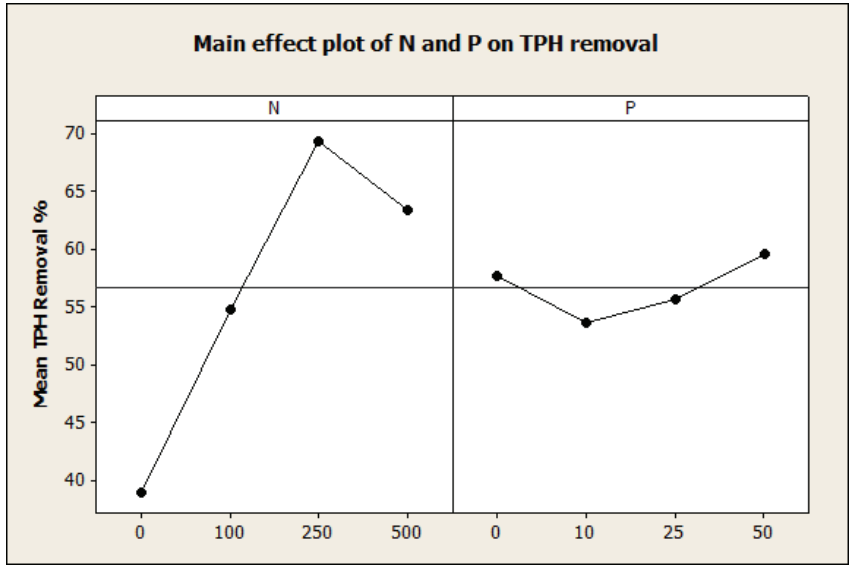

Figure 3. The Main effect statistical analysis of the studied parameters; $\mathrm{N}$ and $\mathrm{P}$ different levels. The results demonstrated that unlike nitrogen source, the addition of phosphate did not cause a significant improvement on the TPH removal.

and $500 \mathrm{ppm}$ of nitrogen, a decline in the population of heterotrophic bacteria occurred henceforth. This result showed that besides to the economic considerations, an excess amount of nitrogen could have a deteriorating effect on the biodegradation rate. Additionally, the amount of nitrogen amendment should be optimized regarding soil conditions.

In contrast, an amendment in phosphate did not significantly influence the growth rate of the soil microbial population. This phenomenon could be due to a sufficient innate phosphate source of the soil.

The comparison between control microcosm (without compost) and the microcosm amended with compost only, demonstrated that addition of the compost caused a permanent increase in the heterotrophic bacterial count of the soil (data not shown).

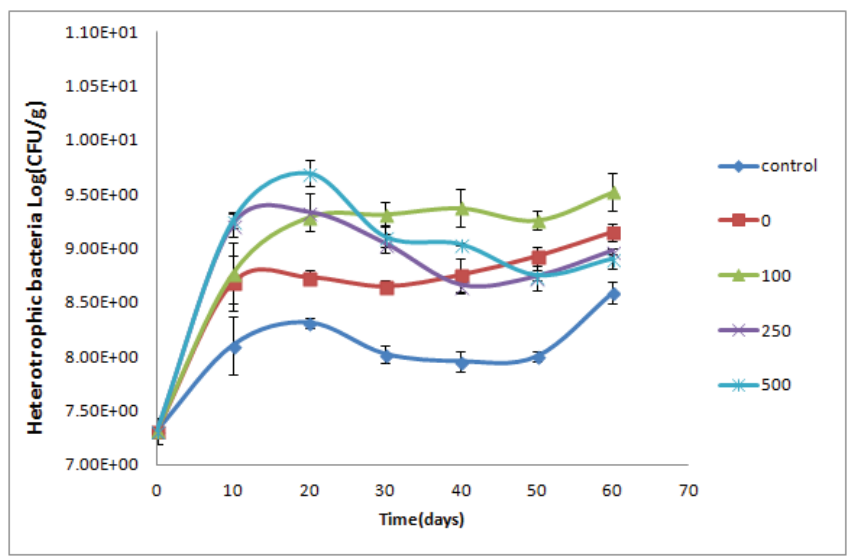

Figure 4. The growth curves of heterotrophic bacteria in the soil amended with various concentration of nitrogen (without phosphate addition). Error bars represent standard deviations of three replicates. 


\section{Discussion}

Considering the gasoil origin of the contamination, the linear and branched aliphatic hydrocarbons were the main constituents of the soil pollution. The sandy soil used in this study was poor in organic matter, thus encompassing a low bacterial population; however, a considerable diversity of the hydrocarbon-utilizing bacteria was observed in the experimental conditions. Actinobacteria, including the genera Gordonia, Nocardia, Nocardioides, and Rhodococcus were the dominanthydrocarbon-utilizingbacteria.Actinobacteria are common in the soil environments, and play a pivotal role in the decomposition of organic matter (8). Genera belonging to family Nocardiaceae have frequently been isolated from hydrocarbons polluted soils. They are a potentially rich source of metabolic diversity and have a high capacity to use different organic pollutants such as aliphatic, halogenated, bicyclic and polycyclic hydrocarbons as the sole carbon and energy sources (27). Similar to previous works, the result of this study indicated the importance and high potential of Nocardiaceae to survive and perform bioremediation in the polluted habitats including saline soil. These results are in agreement with the findings of Crawford and Rosenberg (2013) indicating that a considerable diversity of indigenous hydrocarbon-utilizing bacteria inhabited the contaminated soil and there was no need for bio-augmentation (7). However, biostimulation by moisture and nutrient amendment could significantly increase degradation efficacy.

Statistical analysis of the $\mathrm{N}$ and $\mathrm{P}$ optimization results showed that biodegradation extent was significantly influenced by nitrogen adjustment in a way that a sharp increase in the oil removal was observed by increasing nitrogen source from $0 \mathrm{ppm}$ to $250 \mathrm{ppm}$. Based on these results, it could be concluded that nitrogen amendment was crucial for pollutant removal. Abdul salam et al. (2011) have shown that biodegradation removes 50\% of the oil and grease of the soil contaminated with spent motor oil after incubations for 70 days. When the soil was supplemented with the nutrients ( $\mathrm{N}$ and $\mathrm{P}$ ), $75 \%$ of the spent motor oil was removed. The results demonstrate that a high concentration of nutrient can accelerate the initial spent motor oil biodegradation rate and may shorten the period of clean-up contaminated soil. The increasing effect of the amendment is stronger when nutrient availability is a limiting factor in the bioremediation of soil (28). However, superfluous nitrogen up to $500 \mathrm{ppm}$ showed an inhibitory effect on the microbial activity because higher nitrogen amendment reduced soil water potential and inhibited microbial activity, the same behavior was verified in a study by Walecka-Hutchison et al. (2006) which have evaluated nitrogen optimization for the diesel bioremediation for 41 days $(3,16)$. Conversely, phosphate amendment did not have a profound effect on the achieved biodegradation. In the previous studies, several inorganic and organic forms of phosphate have been reported to be successfully used to bio-stimulate contaminated environments (12), but several other studies have shown that phosphate amendment does not have an effect on the bioremediation process, or that it may inhibit the bio-process by adding too much of this element $(18,29)$. In this study, adding phosphate to the soil did not have a considerable effect on the biodegradation which indicates that phosphate content was not a limiting factor in the prepared microcosms.

\section{Conclusions}

Bioremediation is considered as an efficient practical approach for remediating hydrocarbon-contaminated soils and recently has been suggested for management of the oil-based cuttings and drilling mud pits. Considering both economic aspects and environmental concerns, biostimulation of the soil microflora is generally preferred to amending propagated cultures of exogenous bacteria. In this study, microbial analysis of the untreated soil elucidated the rich diversity of domestic hydrocarbon degrading bacteria which emphasizes the redundancy of microbial augmentation. Among the various factors affecting remediation efficiency, nitrogen and phosphorous have been copiously reported as the important limiting factors. The Main effect statistical analysis showed that nitrogen amendment could be the most effective at 250 ppm and phosphate addition did not cause a significant improvement in the remediation process. In contrast with plant farming where soil nutrients are extracted by plants and removed after harvesting, during soil bioremediation nutrients could be recycled in microbial community and will be retained in the matrix unless soil washing or de-nitrification to nitrogen gas occurs. Considering the cost of the operation and inhibiting the effect of excess nitrogen, $\mathrm{C}: \mathrm{N}: \mathrm{P}$ ratio should be checked individually for any contaminated site prior to the field design.

Collectively, the results confirmed the bioremediation potential of the oil-contaminated drilling mud and the optimized nutrient amendment was shown to create a significant improvement in biodegradation efficiency and cost of operation.

\section{Acknowledgements}

We gratefully appreciate the Iranian Central Oil-fields 
Company (ICOFC) for financial support to this research (contact No. 50-81-30000).

\section{Authors' contributions}

All of the researchers have participated in implementation and preparing various sections of the study (i.e. conception of the research, experimental design, data acquisition, and drafting the manuscript or revising). Moreover, all authors read and approved the final manuscript.

\section{References}

1. Juwarkar AA, Singh SK, Mudhoo A. A comprehensive overview of elements in bioremediation. Rev Environ Sci Biotechnol. 2010;9(3):215-288. doi: 10.1007/s11157-010-9215-6

2. Nikolopoulou M, Pasadakis N, NorfH, Kalogerakis N. Enhanced ex situ bioremediation of crude oil contaminated beach sand by supplementation with nutrients and rhamnolipids. Mar Pollut Bull. 2013;77(1):37-44. doi: 10.1016/j.marpolbul.2013.10.038

3. Pala DM, Carvalho DD, Pinto JC, Sant'Anna GL. A suitable model to describe bioremediation of a petroleum-contaminated soil. Int Biodeter Biodegr. 2006;58(3):254-260. doi: 10.1016/j. ibiod.2006.06.026

4. Grace Liu PW, Chain Chang T, Whang LM, Kao CH, Pan PT, Cheng SS. Bioremediation of petroleum hydrocarbon contaminated soil: effects of strategies and microbial community shift. Int Biodeter Biodegr. 2011;65(8):1119-1127. doi: 10.1016/j.ibiod.2011.09.002

5. Agarry SE, Ogunleye OO. Bioremediation potential of native hydrocarbon degrading bacterial strains in crude oil contaminated soil under microcosm study. Int Biodeter Biodegr.2014;94:79-89. doi: 10.1016/j.ibiod.2014.03.024

6. Crawford R, Rosenberg E. Factorial designs application to study enhanced bioremediation of soil artificially contaminated with weathered bonny light crude oil through biostimulation and bioaugmentation strategy. J Environ Protec. 2012;2012. doi: $10.4236 /$ jep. 2012.38089

7. Crawford RL and Rosenberg E. Bioremediation, In: The Prokaryotes. 2013; Springer.295-307.

8. Prince R, Gramain A and McGenity TJ. Prokaryotic hydrocarbon degraders, In: Handbook of hydrocarbon and lipid microbiology. 2010; Springer.1669-1692.

9. Atlas RM. Microbial degradation of petroleum hydrocarbons: an environmental perspective. Microbiol Rev. 1981;45(1):180.

10. Asquith EA, Geary PM, Nolan AL, Evans CA. Comparative bioremediation of petroleum hydrocarbon-contaminated soil by biostimulation, bioaugmentation and surfactant addition. $J$ Environ Sci Eng. 2012;1(5A).

11. Leahy JG, Colwell RR. Microbial degradation of hydrocarbons in the environment. Microbiol Rev. 1990;54(3):305-315.

12. Timmis KN. Handbook of hydrocarbon and lipid microbiology. 2010: Springer Berlin.

13. Agarry SE, Ogunleye OO. Box-Behnken design application to study enhanced bioremediation of soil artificially contaminated with spent engine oil using biostimulation strategy. Int J Energy Environ Eng. 2012;3(1):1-14. doi: 10.1186/2251-6832-3-31

14. Palanisamy N, Ramya J, Kumar S, Vasanthi NS, Chandran P, Khan S. Diesel biodegradation capacities of indigenous bacterial species isolated from diesel contaminated soil. J Environ Health
Sci Eng. 2014;12(1):1. doi: 10.1186/s40201-014-0142-2

15. Rezaei Kalantary R, Mohseni-Bandpi A, Esrafili A, Nasseri S, Rashid Ashmagh F, Jorfi S., et al. Effectiveness of biostimulation through nutrient content on the bioremediation of phenanthrene contaminated soil. J Environ Health Sci Eng. 2014;12(1):1. doi: 10.1186/s40201-014-0143-1

16. Walecka-Hutchison CM, Walworth JL. Assessment of C: N ratios and water potential for nitrogen optimization in diesel bioremediation. Bioremediat J. 2006;10(1-2): 25-35. doi: 10.1080/10889860600857082

17. Walworth J, Pond A, Snape I, Rayner J, Ferguson S, Harvey P. Nitrogen requirements for maximizing petroleum bioremediation in a sub-Antarctic soil. Cold Reg Sci Technol. 2007;48(2):84-91.doi: 10.1016/j.coldregions.2006.07.001

18. Vieira PA, Faria S, Vieira RB, De Franc FP, Cardoso VL. Statistical analysis and optimization of nitrogen, phosphorus, and inoculum concentrations for the biodegradation of petroleum hydrocarbons by response surface methodology. World J Microbiol Biotechnol. 2009;25(3):427-438. doi: 10.1007/s11274-008-9907-z

19. Alexander M. Biodegradation and bioremediation. 1999: Gulf Professional Publishing.

20. Zhang XX, Cheng SP, Zhu CJ, Sun SL. Microbial PAHdegradation in soil: degradation pathways and contributing factors. Pedosphere. 2006;16(5):555-565. doi: 10.1016/s10020160(06)60088-x

21. Eaton AD, Franson MAH. Standard methods for the examination of water \& waste water. AmerPublic Health Assoc. 20th Rev Ed. Washing ton, DC, USA, 2005. doi: 10.1016/00032697(90)90598-4

22. Samimi SV, Akbari Rad R, Ghanizadeh F. Polycyclic aromatic hydrocarbon contamination levels in collected samples from vicinity of a highway. J Environ Health Sci Eng. 2009;6(1):4752.

23. Margesin, R. and F. Schinner. Manual for soil analysismonitoring and assessing soil bioremediation. Vol.5;2005. Springer Sci Business Med.

24. Margesin R, Schinner F. Preparation of genomic DNA from bacteria. Curr Protoc Mol Biol. 1987;p:2.4.1-2.4.5. doi: 10.1002/0471142727.mb0204s56

25. Kim OS, Cho YJ, Lee K, Yoon SH, Kim M, Na H., et al. Introducing EzTaxon-e: a prokaryotic 16S rRNA gene sequence database with phylotypes that represent uncultured species. Int J Syst Evol Microbiol. 2012;62(3):716-721. doi: 10.1099/ ijs.0.038075-0

26. Tamura K1, Peterson D, Peterson N, Stecher G, Nei M, Kumar S. MEGA5: molecular evolutionary genetics analysis using maximum likelihood, evolutionary distance, and maximum parsimony methods. Mol Biol evol. 2011;28(10): 2731-2739. doi: 10.1093/molbev/msr121

27. Goodfellow M, Maldonado LA. The families dietziaceae, gordoniaceae, nocardiaceae and tsukamurellaceae, In: The prokaryotes. 2006; Springer: 843-888. doi: 10.1007/0-38730743-5_32

28. Abdulsalam S, Bugaje IM, Adefila S, Ibrahim S. Comparison of biostimulation and bioaugmentation for remediation of soil contaminated with spent motor oil. Int J Environ Sci Technol. 2011;8(1):187-194. doi: 10.1590/s1516-89132009000300027

29. Atagana H, Haynes R, Wallis F. Optimization of soil physical and chemical conditions for the bioremediation of creosotecontaminated soil. Biodegradation.2003;14(4):297-307. 